\title{
Comparative Studies on the Glycogenetic Actions of Sulfonylurea, Mesoxalate and Insulin
}

\author{
By \\ Jiro KURANARI \\ II Division of Internal Medicine, Kobe Medical College
}

The present study was undertaken to compare the glycogenetic action of sulfonylurea, mesoxalate and insulin by rat's liver and muscle (diaphragm) injected these substances daily for seven days, especially the relation between this action and nutritious components, and the following results have been obtained :

(1) Mesoxalate and insulin have shown marked promoting effects on the formation of liver glycogen from carbohydrate source, and insulin caused inhibitory effect on glycogenesis of liver from protein source.

(2) Increased effect on body weight and decreased effect on blood sugar have been observed in sulfonylurea treated rats from fat nutrition.

(3) As far as the glycogenesis from carbohydrate source of rats diaphragm, these three drugs showed almost same significant promoting effects.

\section{Histological Studies on the effect of antithyroid drugs upon the pituitary thyroid system}

\author{
By
}

\section{Hutoshi IIDA, Etsushi SANO and Rikio FURIHATA}

Department of Surgery, Faculty of Medicine, Shinshu University (Director: Prof. K. Maruta)

In order to clarify the acting mechanism of antithyroid drugs the histological studies on the thyroid and anterior pituitary of rabbits were performed following the administration of methylthiouracil, Imethyl-2-mercaptoimidazole or inorganic iodine. The following results were obtained.

1. Methylthiouracil may directly suppress the function of the thyroid and secondarily stimulate the release of TSH from the anterior pituitary in vivo. The direct action of methylthiouracil to the anterior pituitary, however, is not completely proven.

2. It may be deduced that 1-methyl-2-mercaptoimidazole suppresses not only the function of the thyroid, but also suppresses the release of TSH from the anterior pituitary.

3. Inorganic iodine may be considered to suppress first the release of TSH from the anterior pituitary and secondarily suppress the function of the thyroid. 


\title{
「ズルファニール尿素,「メゾ|葰酸及び「インシュリン」の 造糖原促進能比較に関する実験的研究
}

\author{
神戸医科大学第二内科学教室 (指導辻尔正垐前教授) \\ 倉成 二 郎
}

(I) 緒

言

従来血糖低下作用物質は多数に見出されたが，其臨床治療目的上の使用可否を決するのには其血糖低下作 用機序，特に其抗糖尿病作用性能に就いて慎重に検討せられねばならない.

嘗て血糖低下作用物質として臨床目的にあ使用せられた Synthalin には，動物の肝に於ける游離糖及び糖 原量を激減せしむる作用のあるのを教室から (松浦 ${ }^{1}$ ) 報告せられ其抗傏尿病作用の無い事を証せられた. insulin（以下「イと略す）と肝，筋糖原量との問題に就いては既に極めて多数の報告があつて，各報告者 の意見が全然一致して居るとは云えないが，多数の報告は肝，筋糖原量の增加に一致して居る. 元来「イ」 の様に糖の phosphorylation を催進する事が大である血糖作用物質に就いて，其肝，筋糖原量との関係を決 定するのには，「イ」注射量，注射回数，造糖物質同時注射の有無，其他動物の個体差，季節差等によつて， 同様正常代謝動物であ相当な相違を見るべきは当然と考えられる，其処で「イ」と Synthalin との抗糖尿病 作用性能比較に於いては，教室では其極端な場合である大量注射（低血糖症状時）方法か取られ，其結果 Synthalin,「グアニヂン」，「ヒドラチン」等は其血糖低下作用は「イ」に比して知んど優劣を認めないが， 其大量注射後に於ける肝糖原量に於いて極めて明確な相違のある事を明かにした(松浦 ${ }^{12}$ ，中野等 $\left.{ }^{22}\right)$.

「メゾ滺酸と肝，筋糖原量との関係に就いては既に正常並びに「アロキサン」糖尿鬼に就き in vivoに竹田 等 ${ }^{3)}$ ，in vitro 亿馬場 ${ }^{4)}$ ，中井 ${ }^{5}$ ，等によつてせられた報告によつて，其肝，筋に於ける糖原増加作用のある 事を明にせられて居る。

ズルファニール尿素郕（S.U.と略す）の血糖降下作用機序は目下の処不明であるが，其臨床使用に当つて は其抗糖尿病作用比較として先づ第一に肝，筋に於ける糖質像との間の関係を明にすべきが至当と考えられ

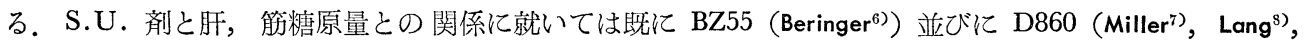

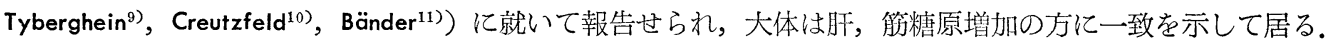
然し一部の報告者 (Beringer ${ }^{(6)}$ ，Miller ${ }^{7)}$ ，Creutzfeld ${ }^{10)}$ ) は筋糖原の增加を認めず，此の点を以て「イ」作用 との重要相違点の一に挙げて居る.

総体に鼠の䀒糖原量の個体差及び季節差は他の動物に比較すれば少いのではあるが，それであ相当程度に 認められる．それ故只一回の試薬投与後の検査のみでは極めて著明な差違を生ずる場合以外は其判定が困難 である.

又余り長時間の試薬投与後に於ける検査では試薬の主作用以外の他の因子（季節，試薬の副作用）による影 響が比較的強く現われ得る可能性が考えられる。故に本実験では試薬投与を 7 日間とし，試薬投与量は鼠の 発育に障害を与えない程度とした，尚其上に投与試薬が朋，筋の糖質像に対して影響するものとすれば，其 如何なる主食成分に対して最も著名な影響を与うるすのであるかどうかを見る為に，鼠鸰青を混合食，糖貿 食，蛋白食及び脂質食の 4 種類とし，其各場合に就いて試薬を与えた場合と其対照とを同時に実験し，全場 合共に離食後 6 時間に屠殺して其肝総糖量，糖原量及び筇（横隔膜）糖原量を測つて，各種試萝による影響 を夫々の対照の場合と比較した。

斯くして各種試薬の抗糖尿病作用性能比較の上に於いて重要な位置を占むる肝，筋糖賴像の上から，各種 試薬の抗糖尿病作用性能を比较せんとしたのである. 


\section{（II）実 験 方 法}

実験動物は体重100gm内外のウイスター系純系白鼠で，予め一定期間混合食で飼育して其生活状況を観察 しながら健常な鼠のみを実験に供した。

実験に際しては次の各飼育食群に分けた。

（1）混合食飼育群：オリエンタル固形食 1 日投与量 $15 〜 20 \mathrm{gm}$.

（2）糖質食飼育群：甘藷 $42 \mathrm{gm}$ と $50 \%$ 葡萄糖液 $2 \mathrm{cc}$ （葡萄糖はゾンデで胃内に注入）.

（3）蛋白食飼育群: 牛の挽肉 $26 \mathrm{gm}$.

（4）脂質食飼育群：バター $5 \mathrm{gm}$ とオリエンタル固形食 $1 \mathrm{gm}$. バターのみでは鼠の発育が悪いので固形混 合食を附加した.

各食餌共 1 日約 $50 \mathrm{ca} 1$ とし，別に食塩，綜合ビタミン，無機塩を加えた。

上記各群の鼠を更と略同体重の 2 群に分け，甲群には食餉と同時に一定の抗糖尿病治療剂を筋注（午後 7 時頃)，7 日間続けて第 8 日目の午前 7 洔に離食其後 6 時間目に屠殺し肝総糖量と糖原量（山本法 ${ }^{12)}$ ), 横隔 膜糖原量 (乗金法 ${ }^{13)}$ ) 及び心臟内血糖量 (Hagedorn-Jensen法 ${ }^{14)}$ )を測定し，同様に検測した乙群（刘照群，抗

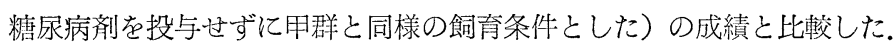

離食後屠殺迄の時間を 6 時間としたのは空腹による肝，筋糖原減少が余り䓕しくなく而も糖原の比較的安 定な時間をとつたためである (予借実験 ${ }^{(j)}$ ).

尚肝，横隔膜は重量を測定して糖質量は全量 $(\mathrm{mg})$ で表現した。

又抗糖尿病片の注射量は BZ55. D860. IBTD (P-aminobenzene-sulfamido-isobutyl-thiodiazole) 及び「メ ゾ」落酸 Naは 1 日 1 回 $20 \mathrm{mg}$ 宛,「イ」は 1 日 1 回 $0.1 \mathrm{u}$ 宛とした。

\section{（III）実 験 成 績}

第 1 表 B Z 55投与( $20 \mathrm{mg}$ 宛 7 日間皮注)鼠体重. 血糖及び肝, 横隔膜糖質像（平均値）

\begin{tabular}{|c|c|c|c|c|c|c|c|}
\hline & & 例 & $\begin{array}{c}\text { 体重 } \\
(\mathrm{gm})\end{array}$ & $\left(\begin{array}{c}\mathrm{mg} \\
\%\end{array}\right)$ & $\begin{array}{l}\text { 肝 } \\
\text { 総糖量 } \\
\text { (mg) }\end{array}$ & $\begin{array}{l}\text { F } \\
\text { 糖原量 } \\
\text { ( } \mathrm{mg})\end{array}$ & \begin{tabular}{|l} 
横隔膜 \\
糖原量 \\
(mg) \\
\end{tabular} \\
\hline \multirow{3}{*}{$\begin{array}{l}\text { 混 } \\
\text { 合 } \\
\text { 食 }\end{array}$} & 照群 & 3 & 129 & 120 & 183.1 & 101.2 & 0.89 \\
\hline & $\begin{array}{r}\text { B Z } 55 \\
\text { 投与群 }\end{array}$ & 4 & 133 & 116 & 196.6 & 111.6 & 1.01 \\
\hline & \multicolumn{2}{|l|}{$\begin{array}{c}\text { 増減率 } \\
(\%)\end{array}$} & +3.1 & -3.3 & +7.4 & +10.3 & +13.5 \\
\hline \multirow{3}{*}{$\begin{array}{l}\text { 糖 } \\
\text { 質 } \\
\text { 食 }\end{array}$} & 対照群 & 6 & 107 & 99 & 237.3 & 133.0 & 0.70 \\
\hline & $\begin{array}{r}\text { B Z } 55 \\
\text { 投与群 }\end{array}$ & 6 & 108 & 101 & 245.9 & 138.2 & 0.77 \\
\hline & \multicolumn{2}{|l|}{$\begin{array}{c}\text { 増減率 } \\
(\%)\end{array}$} & +0.9 & +2.0 & +3.6 & +3.9 & +10.0 \\
\hline \multirow{3}{*}{$\begin{array}{l}\text { 蛋 } \\
\text { 白 } \\
\text { 食 }\end{array}$} & 対照群 & 3 & 145 & 107 & 142.6 & 64.2 & 1.53 \\
\hline & $\begin{array}{c}\text { B Z Z 55 } \\
\text { 投与群 }\end{array}$ & 3 & 146 & 100 & 144.4 & 56.0 & 1.42 \\
\hline & $\begin{array}{c}\text { 増減率 } \\
(\%)\end{array}$ & & +0.7 & -6.5 & +1.3 & -12.8 & -7.2 \\
\hline \multirow{3}{*}{ 脂 } & 対照群 & 4 & 108 & 104 & 212.3 & 138.9 & 0.70 \\
\hline & $\begin{array}{r}\text { B Z } 55 \\
\text { 投与群 }\end{array}$ & 3 & 119 & 93 & 182.7 & 125.7 & 0.71 \\
\hline & $\begin{array}{c}\text { 増減率 } \\
(\%)\end{array}$ & & +10.2 & -10.6 & -13.9 & -9.5 & +1.4 \\
\hline
\end{tabular}

第 2 表 $D 860$ 投与 $(20 \mathrm{mg}$ 宛 7 日間皮注)鼠体重， 血糖及び肝，横隔膜糖質像（平均值）

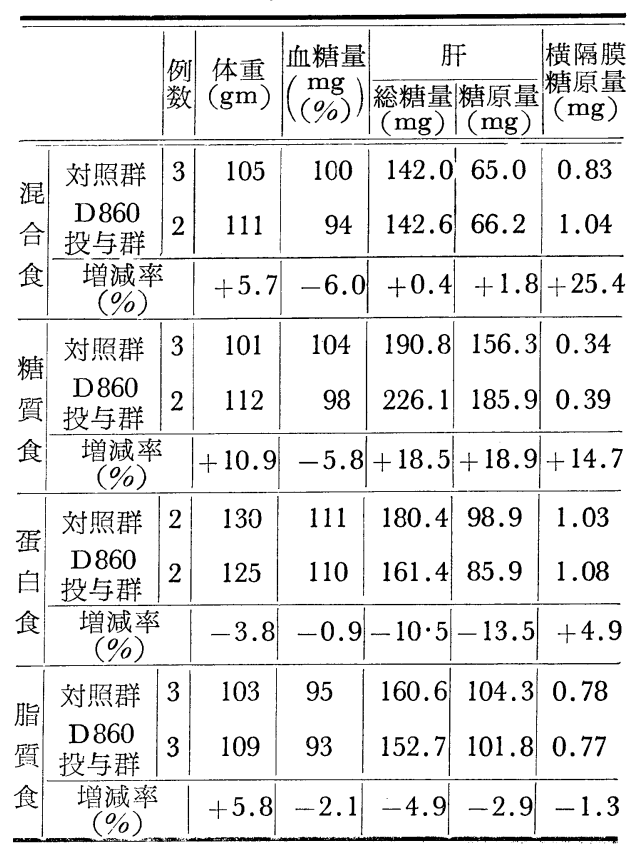


第 3 表 IBTD投与 $(20 \mathrm{mg}$ 宛 7 日間皮注) 鼠体重,

血糖及び肝，横隔膜糖質像（平均値）

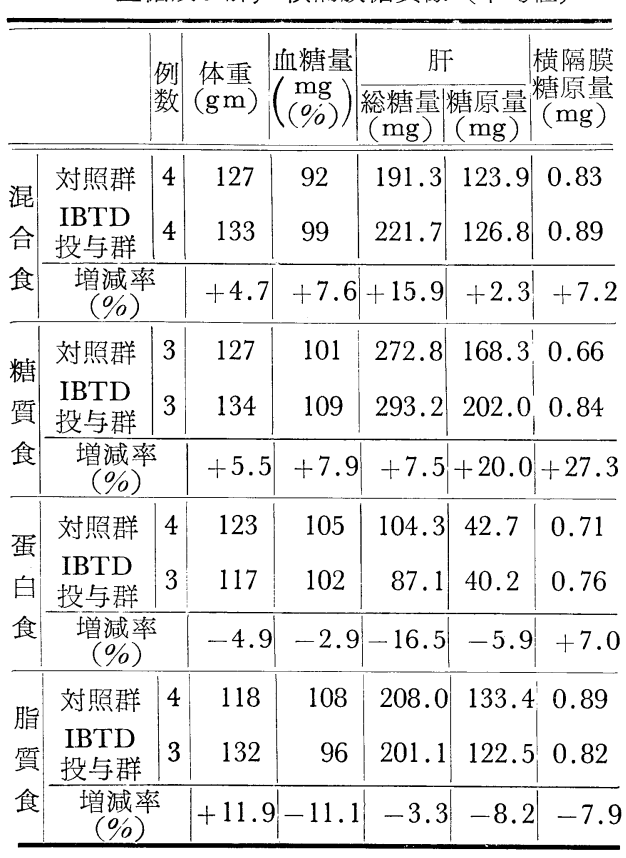

第 4 表 各種食䬲飼育鼠の体重，血糖， 肝並びに筋糖原量に及ぼす 3 種 S.U.率の作用比較增減率表 $\begin{array}{lll}\text { (A) } \cdots \text { B Z } 55 & \text { (B) } \cdots \text { D } 860 & \text { (C) } \cdots \text { IBTD }\end{array}$

\begin{tabular}{r|r|r|r|r}
\hline & 体 重 & 血糖量 & 肝糖原量 & 筋糖原量 \\
\hline \hline (A) & +3.1 & -3.3 & +10.3 & +13.5 \\
混合食 (B) & +5.7 & -6.0 & +1.8 & +25.4 \\
(C) & +4.7 & +7.6 & +2.3 & +7.2 \\
\hline (A) & +0.9 & +2.0 & +3.9 & +10.0 \\
糖質食 (B) & +10.9 & -5.8 & +18.9 & +14.7 \\
(C) & +5.5 & +7.9 & +20.0 & +27.3 \\
\hline 蛋白食 (B) & -3.8 & -0.9 & -13.5 & +4.9 \\
(C) & -4.9 & -2.9 & -5.9 & +7.0 \\
\hline (A) & +10.2 & -10.6 & -9.5 & +1.4 \\
脂質食 (B) & +5.8 & -2.1 & -2.9 & -1.3 \\
(C) & +11.9 & -11.1 & -8.2 & -7.9 \\
\hline
\end{tabular}

（A） 3 種 S.U.刻（BZ55, D860. IBTD）の各種食慨飼育鼠の体重, 血糖及び肝, 筋糖質像に及ぼす作用比較

3 種 S.U.剂 (BZ55，D860及び IBTD) の鼠体重，血糖，肝総糖量，糖原量及び筋糖原量に対する影響 は第 $1,2,3$ 表で知られる通りであるが今其対照と比較した場合の増減比較を增減率で示した第 4 表でみる と，体重並びに血糖量に対しては各種食䬦飼育鼠に対して 3 種製剤間に何等特異な相違は無いが，脂質食餌 飼育鼠では 3 種薬鼡共に其体重の増加と血糖の低下とを証せられた。

肝糖原量に対しては 3 種薬剤間に特異な差違は認められなかつたが，糖質食に於ける D860 と IBTD に よる肝糖原増量が稍著明であつた。

笳糖原量に対してあ肝の場合と略同様であつたが，此揚合には混合食に於ける D860，糖質食に於ける IBTD の糖原増量が稍著明であつた.

肝と筋に於ける糖原量の増減率を比較すると，総体的に増量率では筋の方が朋よりも比較的大であつたし， 肝に於いて減少を示した場合が筋では増量となつて居るか或いは其減少率を減じている。

\section{（B）「メゾ」苳酸塩の各種食餌飼育鼠体重，血糖及び肝，筋糖啠像に対する影響}

体重は各種食餌飼育鼠共に増量を示し各種食餌間に差違を認めない.

血糖量も混合食以外は軽度ながらも低下を認められる。

肝総糖量並びに糖原量に対しては混合食と糖質食飼育群に対して稍著明な堌量を示し，蛋白食並びに脂質 食鼠に対しては殆んど変化を認めない。

朌糖原量も肝糖原量と其增減度は並行して居る (第 5 表参照).

\section{（C）「イ」の各種食慨飼育鼠体重，血糖，及び肝，筋糖質像に対する影響}

体重は蛋白食以外の各種食餌飼育鼠に増量的に作用し，血糖の变化は殆んど認められない。乙れは正常鼠 であると云う事，及び「イ」注射と血糖検査との間に比較的長時間の間隔があると云う事に因ると思われる。

肝，筋糖原量に対しては「メゾ」苳酸の場合と同様に，混合食と糖筫食とで稍著明な増量を見られた。只 「イ」の場合では蛋白食で肝糖質に稍著明な減量を証せられて居るのが他の「メゾ」蓚酸や S,U.骭では見 
第 5 表 メゾ葆酸 $\mathrm{Na}$ 投与 $(20 \mathrm{mg}$ 宛 7 日間皮注) 鼠体重，血糖及び肝，横隔膜糖質像 (平均值)

\begin{tabular}{|c|c|c|c|c|c|c|c|}
\hline & & $\begin{array}{l}\text { 例 } \\
\text { 数 }\end{array}$ & $\begin{array}{l}\text { 体重 } \\
(\mathrm{gm})\end{array}$ & $\left(\begin{array}{c}\text { 血糖量 } \\
\left(\begin{array}{c}\mathrm{mg} \\
(\%)\end{array}\right)\end{array}\right.$ & $\begin{array}{l}\text { 月 } \\
\text { 総糖量 } \\
\text { | (mg) }\end{array}$ & 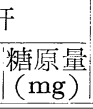 & $\begin{array}{l}\text { 横隔膜 } \\
\text { 糖原量 } \\
(\mathrm{mg})\end{array}$ \\
\hline 17 & 対照群 & 3 & 125 & 98 & 300.5 & 177.7 & 0.79 \\
\hline 合 & $\begin{array}{cc}\text { メ } & \ddots ゙ \\
\text { 投与群 }\end{array}$ & 2 & 136 & 99 & 334.6 & 232.2 & 0.96 \\
\hline 食 & $\begin{array}{c}\begin{array}{c}\text { 増減率 } \\
(\%)\end{array}\end{array}$ & & +8.8 & $|+1.0|$ & +11.1 & +30.7 & +21.5 \\
\hline 糖 & 対照群 & 2 & 116 & 111 & 222.7 & 169.3 & 0.82 \\
\hline 質 & $\begin{array}{cc}x & \ddots ゙ \\
\text { 投与群 }\end{array}$ & 3 & 125 & 105 & 299.2 & 232.9 & 1.03 \\
\hline 食 & $\begin{array}{c}\text { 増減率 } \\
(\%)\end{array}$ & & +7.8 & -5.4 & +34.4 & +37.5 & +25.6 \\
\hline & 対照群 & 3 & 119 & 95 & 167.9 & 52.6 & 0.67 \\
\hline 白 & $\begin{array}{cc}x & \ddots ゙ \\
\text { 投与群 }\end{array}$ & 3 & 128 & 87 & 168.1 & 54.0 & 0.66 \\
\hline 食 & $\begin{array}{c}\text { 増減率 } \\
(\%)\end{array}$ & & +7.6 & $|-8.4|$ & +0.1 & +2.7 & -1.5 \\
\hline 肶 & 対照群 & 3 & 119 & 92 & 207.3 & 120.9 & 0.58 \\
\hline 質 & 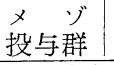 & 3 & 124 & 90 & 203.8 & 115.1 & 0.58 \\
\hline 食 & $\begin{array}{c}\text { 増減率 } \\
(\%)\end{array}$ & & +4.2 & -2.2 & -1.7 & -4.8 & \pm 0 \\
\hline
\end{tabular}

第 6 表 インシュリン投与( 0.1 u宛 7 日間皮注) 鼠体重，血糖及び肝，横隔膜糖質像 (平均值)

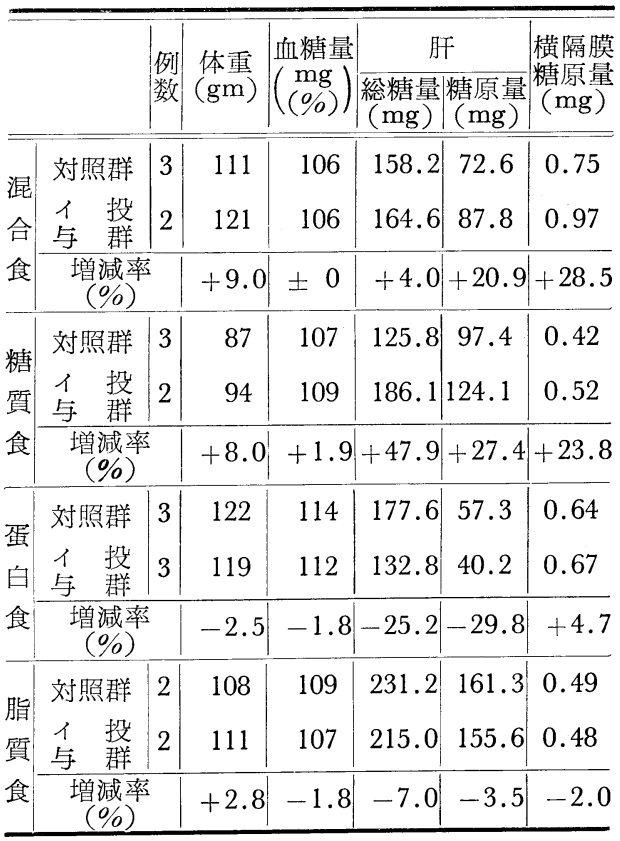

第 7 表 S.U.剂，メゾ鉴酸及びインシュリンの鼠体重 並びに血糖量に及ぼす影響比較（各場合対照と の比較に於ける増減率\%)

\begin{tabular}{|c|c|c|c|c|c|c|}
\hline & \multicolumn{2}{|c|}{ 体 } & & \multicolumn{2}{|c|}{ 血 } & 年 量 \\
\hline & S.U.剂 & メゾ莜酸 & $\mid$ インシュリン| & S.U.剂 & $\mid$ ×ゾ落酸| & インシュリン \\
\hline 混合食 & +4.5 & +8.8 & +9.0 & -0.5 & +1.0 & \pm 0 \\
\hline 糖質食 & +5.8 & +7.8 & +8.0 & +1.4 & -5.4 & +1.9 \\
\hline 蛋白食 & -2.6 & +7.6 & -2.5 & -3.4 & -8.4 & -1.8 \\
\hline 脂質食 & +9.3 & +4.2 & +2.8 & -8.6 & -2.2 & -1.8 \\
\hline
\end{tabular}

られなかつた事柄である (第 6 表参照).

（D） S.U.剤，「メゾ」荫

酸及びインシュリ ンの各種食慨飼育 鼠体重, 血糖, 䀒 並びに筋糖原量に 及ぼす影響の比較

(a) 体重並びに血糖に 及ぼす影響の比較（第 7 表 参照)

体重に対しては混合食及び糖質食では 3 者の間に殆んど差違を認めない，蛋白食では「メゾ」蓚酸のみが 増加を示し，脂質食では S.U.殽による増量が稍著明である.

血糖量でも 3 試薬の間に殁んど差違を認められないが，只 S.U.剂による脂質食に対する血糖の減少が稍 著明であるのみである。

(b) 肝並びに筋糖原量に及ばす影響の比較

肝糖原量では混合食と糖質食とに対して「メゾ」蓚酸と「イ」とによる増量が稍著名であり，蛋白食に対 する「イ」とS.U.骭とよる減量が稍著明である.

筋糖原量では混合食と糖質食とに対する「イ」，「メゾ」蓚酸立びに S.U.殽 3 者共に稍著明に増量を見， 蛋白並びに脂質食に対しては 3 者共に殆んど変化を㒻ない. 
第 8 表 抗糖尿病性 S.U. 剂, メゾ蓚酸及び インシュリンの鼠肝糖原量に及ぼす影響（各 場合対照との比較に於ける増減率\%)

\begin{tabular}{l|c|c|c}
\hline & S.U.剤 & メゾ蓚酸 & インシュリン \\
\hline \hline 混合食 & +4.8 & +30.7 & +20.9 \\
糖質食 & +14.3 & +37.5 & +27.4 \\
蛋白食 & -10.7 & +2.7 & -29.8 \\
脂筫食 & -6.9 & -4.8 & -3.5 \\
\hline
\end{tabular}

第 9 表 抗糖尿病性 S.U.殽，メゾ蓚酸及び インシュリンの鼠横隔膜糖原量に及ぼす影響 各場合対照との比較に於ける増減率\%)

\begin{tabular}{c|c|c|c}
\hline & S.U.敦 & メゾ蓚酸 & インシュリン \\
\hline 混合食 & +15.4 & +21.5 & +28.5 \\
糖質食 & +17.3 & +25.6 & +23.8 \\
蛋白食 & +1.6 & -1.5 & +4.7 \\
脂質食 & -2.6 & \pm 0 & -2.0 \\
\hline
\end{tabular}

\section{(IV) 討}

\section{議}

各種相違した 4 種類の主食飼育鼠の体重，血糖，肝並びに符糖質像に対する影響で特異な变化を旱した場 合の態度を求めると，

（a）脂質食に於ける S.U.率による体重増加と血糖減少の態度

（b）蛋白食に於ける「イ」による肝糖原減少の態度

等である.

次に 3 種試薬に於ける相似的態度を求めると

(a)「メゾ」蓚酸並びに「イ」による混合食及び糖質食に於ける肝糖原増量の態度

（b）混合食及び糖質食に於ける筋糖原に対する 3 種試薬（S.U.剂，「メゾ」蓚酸及び「イ」）による増量 態度等である.

今上記特異若くは相似的態度を総括した結果から次の事項を窅う事が出来た。

(1)「メゾ、葆酸と「イ」とは「イ」に於ける蛋白食鼠に対する肝糖原減少態度以外は各種検査成績に於い て極めて相似的な態度を持して居る。蛋白食鼠の肝糖原量が「イ」によつて特に稍著明な減少を示したのは， 「アミノ」酸からの造糖が「イ」によつて抑制を受けた結果であると想定せられる。

此想定は既に $\mathrm{Bach}^{16)}$ ，Stadie' ${ }^{17}$ 等によつて「アミノ」酸から蛋白への合成が「イ」によつて促進せられ ると云う実験事実と照して無理の無い考え方であると思われるのである.

（2）S.U.剂は脂質食鼠の体重, 血糖量に対する態度から見て, 他の「イ」や「メゾ」蓚酸とは其糖質代謝 に対する作用が相暴して居ると考えられる。即ちS.U. 郕で地他の「メゾ」蓚酸や「イ」と相違して特に脂 質食鼠に対する体重増加と血糖低下とが稍著明である。本結果から見ると S.U. 剂は脂質からの造糖を抑制 するやに見受けられる。

（3）肝糖原に対して特に混合及び糖筫食の場合に S.U. 剤では他の「メゾ」蓚酸や「イ」と比較して，其 増加が著明で無い，然るに横隔膜筋では 3 者薬剤間に差程の差違を認めない.

此結果から観ると，末稍に於ける糖原造成作用と云う点では 3 者薬剤間に差程の差違は無いものと考えら れる。

\section{(V) 総括}

$\Gamma メ ソ ゙$ 莜酸,「イ」及び S.U. 製剤等の血糖低下作用物質に就いて其抗糖尿病作用性能を比較する為に，各 種食餌（混合食，糖質食，蛋白食及び脂質食）飼育鼠に夫々の試薬を７日間投与して後，其体重，血糖，旰 総糖質量, 糖原量及び横隔膜笳糖原量に及ぼす作用を, 各種食餌飼育対照鼠と比較して次の結果を得た。

(1) 3 種S.U.棛（BZ55，D860 及びIBTD）間には体重，血糖，肝，筋糖原量上で各種食餌飼育各場合に 於て有意の差違を認めない.

（2）体重と血糖量とではS.U. 剂投与による脂筫食鼠に於ける体重の増加と血糖の低下とが，他の 2 剤と 比較して特異であつた。 
(3) 旰糖原量では混合並びに糖質食鼠に於ける「メゾ」苳酸並びに「イ」による糖原量の增加が稍著明で あり，蛋白食鼠に於ける「イ」による娍量が特異であつた。

（4）横隔膜筋の糖原量に対しては 3 者薬片間に殆んど差違を認めない，混合並びに糖質食鼠に対する糖原 増加が 3 者薬剂共に稍着明であつた。

（5）以上の結果から観ると，抗糖尿病作用性能上「メゾ」蓚酸と「イ」との間には多くの相似点を見出さ れる. 又 S.U. 敦の脂質食鼠に於ける体重と血糖量とに対する態度は他の 2 剂と比較して特異であつた。

本論文の要旨は第30回日本内分泌学会総会（昭和32年 4 月）席上で報告した。

\section{参 考 文 献}

1) 松浦: J.Biochem. 17, 441, 1933.

中野, 若林: Endocrinol. jap. 2, 171, 1955.
2) 中野他 : Hyogo J. Med. Sc. 1, 71, 1951.

4) 馬場 : Endocrinol. jap. 3, 50, 1956,
3) 竹田,

5) 中井 : Endocrinol. jap. 3, 23, 1956.

6) Beringer, A. \& A. Lindner : Wien klin. Wschr. 68, 316, 1956. 7) Miller, W.L. Jr. \& W.E. Dulin : Science, 123, 584, 1956.

8) Lang, S. \& S. Sherry : Metabol. 5, 733, 1956. 9) Tyberghein, J.M., Y.D. Halsey \& R.H. Williams : Pro. Soc. Exper. Biol. Med. N.Y.92, 322, 1956. 10) Creutzfeld, W. \& H. Sütterle : Experimental \& Clinical Studies of the Oral Therapy of Diabetes Mellitus, Hoechst, III, 159 11) Bänder, A. \& J. Scholz : Dtsch. med. Wschr. 22, 889, 1956. 12) 山本: J. Biochem. 32, 389, 1940. 13）乘金 : 京府大誌，36，527，1942. Hagedorn, H.C. \& B.N. Jensen : Biochem. Z. 135, 46, 1923.

15）蒼成：日本内分泌学会誌，掲載予定 Vol. 34, No. 7, 1958).

16) Bach, S.J. \& E.C. Holmes : Biochem. J. 31, 89, 1937.

17) Stadie, W.C. : J. Biol. Ghem. 132, 3931940. 